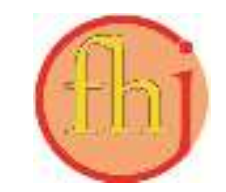

Faletehan Health Journal, 8 (1) (2021) 22-30

www. journal.Ippm-stikesfa.ac.id/ojs/index.php/FHJ

ISSN 2088-673X | e-ISSN 2597-8667

\title{
Studi Kualitatif Strategi Koping Penderita HIV AIDS di Kota Bandung
}

\author{
Salami Salami ${ }^{1 *}$, Annisa Ayu Muvira ${ }^{1}$, Perla Yualita $^{1}$ \\ ${ }^{1}$ Program Studi Sarjana Keperawatan, Sekolah Tinggi Ilmu Kesehatan Aisyiyah Bandung \\ *Corresponding Author: salamisuyanto14@gmail.com
}

\begin{abstract}
Abstrak
HIV/AIDS merupakan penyakit kronis yang dapat menimbulkan dampak negatif berupa masalah fisik, psikis, sosial, dan spiritual sehingga mengakibatkan orang dengan HIV/AIDS hidup dengan penuh tekanan karena isu negatif dan stigmatisasi. Hal ini dapat menjadi masalah bagi kejiwaan penderitanya sehingga memerlukan mekanisme koping ke arah adaptive. Strategi koping menentukan keberhasilan individu dalam menghadapi tekanan. Penelitian ini bertujuan mengeksplorasi strategi koping pada penderita HIV AIDS dengan menggunakan metode penelitian deskriptif kualitatif. Pengumpulan data menggunakan teknik in-depth interview terhadap 6 partisipan secara purposive sampling. Teknik analisis data yang digunakan adalah analysis interactive Miles dan Huberman. Hasil penelitian didapatkan 6 tema yaitu Pasrah pada Tuhan; Tidak ingin memikirkan penyakit; pengalihan masalah; Berupaya untuk bangkit; Upaya mengatasi masalah; dan Menyembunyikan status kesehatan. Berdasarkan penelitian ini dapat disimpulkan bahwa keenam partisipan memiliki kecenderungan melakukan emotion-focused coping. Bagi perawat diharapkan dapat menjalankan strategi intervensi dengan memberikan konseling maupun edukasi strategi koping yang adaptif kepada penderita dan keluarganya.
\end{abstract}

Kata Kunci: Strategi Koping, HIV/AIDS, Analisis Miles dan Huberman, Studi Kualitatif

\section{A Qualitative Study of Coping Strategies among People Living with HIV/AIDS in Bandung}

\begin{abstract}
HIV/AIDS is a chronic disease that causes negative impacts in the form of physical, psychological, social, and spiritual problems that subsequently lead people living with HIV/AIDS to live a stressful life. Negative issue and stigmatization issues are also sources of pressure experienced by survivors. They may result in psychiatric disorders which require survivors to have adaptive coping mechanisms. Coping strategies determine an individual's success in overcoming the pressure. This study aimed to explore coping strategies among survivors by using a qualitative descriptive research method. Interactive analysis model by Miles and Huberman was utilized as the data analysis technique. The data were obtained through semi in-depth interviews which involved 6 participants who were selected by purposive sampling. A total of 6 themes were obtained, namely resignation to God, unwilling to assume about the illness, diversion of problems, attempts of rising up, efforts to overcome problems, and concealment of health status. The researchers concluded that the six participants had a tendency to apply emotion-focused coping techniques. Nurses are therefore recommended to employ intervention strategies by providing counselling and education to people living with HIV/AIDS and their family. Keywords: Coping Strategy, HIV/AIDS, Miles and Huberman Analysis, Qualitative Study
\end{abstract}


Faletehan Health Journal, 8 (1) (2021) 22-30

\section{Pendahuluan}

HIV AIDS merupakan penyakit infeksi yang mematikan disebabkan oleh human immunodeficiency virus), yang menyerang sistem kekebalan tubuh, dengan menghancurkan sel CD4 (cluster differentiation 4). HIV dapat berkembang menjadi AIDS (Acquired Immune Deficiency Syndrome) yaitu stadium akhir dari infeksi virus ini. Pada tahap ini kemampuan tubuh untuk melawan infeksi yang masuk sangat rendah sehingga sangat rentan terhadap berbagai infeksi. Kebanyakan penderitanya meninggal akibat infeksi opurtunistik yang menyertai penyakitnya (Nursalam. \& Kurniawati N.D., 2007).

Prevalensi kasus HIV/AIDS masih menjadi masalah kesehatan di Indonesia dan banyak negara di seluruh dunia. Jumlah kasus infeksi HIV terus meningkat dari tahun ke tahun sejak pertama kali dilaporkan tahun 1987. Secara nasional, Jawa Barat masih termasuk ke dalam lima provinsi dengan kasus HIV/AIDS tertinggi (Kementrian Kesehatan RI, 2018)

Berdasarkan Profil kesehatan Jawa Barat tahun 2017, Kota Bandung dari tahun 1989 sampai dengan 2017 memiliki kasus HIV positif tertinggi mencapai 6882 kasus (Dinas Kesehatan Provinsi Jawa Barat, 2017). Hal ini menunjukkan bahwa HIV/AIDS sudah menjadi ancaman bagi masyarakat luas karena selain mengancam nyawa penderita sendiri, penyakit ini berisiko terhadap penularan yang akan meningkatkan prevalensi kasus penyakit tersebut. Meningkatnya kasus penyakit HIV/AIDS dapat menjadi masalah dalam kejiwaan penderitanya, karena penyakit ini menyebabkan individu mengalami berbagai macam tekanan.

Meskipun terdapat penurunan angka kematian karena keberhasilan terapi anti retroviral (ARV) tetapi dampak signifikan penyakit ini sangat berhubungan erat dengan masalah masalah psikososial penderitanya (Silva et al., 2018). Orang dengan HIV AIDS (ODHA) akan mengalami berbagai macam permasalahan dalam hidupnya yang diakibatkan oleh dampak penyakitnya.

Penelitian yang dilakukan oleh (Pardita \& Sudibia, 2016) menunjukkan bahwa individu setelah dinyatakan mengidap HIV/AIDS mengalami kondisi psikologis yang kompleks yaitu stres, frustasi, kecemasan, kemarahan, penyangkalan, berduka, dan rasa malu. Masuknya
HIV ke dalam tubuh merupakan stressor biologis yang berdampak luas pada penderitanya hal ini diakibatkan oleh dampak dan gejala fisik yang muncul, efek obat yang diminum, ketakutan akan kematian hingga masalah sosial termasuk stigma dan diskriminasi masyarakat. Dampak sosial yang muncul akibat stigma pada penderita HIV AIDS dapat memunculkan berbagai persoalan yaitu memburuknya kondisi fisik akibat ketidakmampuan mengakses pelayanan kesehatan, pendidikan dan terbatasnya akses ekonomi (Dahlui et al., 2015; Mutumba et al., 2015; Priharwanti \& Raharjo, 2018)

Disamping permasalahan fisik, psikologis dan sosial, permasalahan lain yang teridentifikasi adalah permasalahan spiritual. Penelitian yang dilakukan di RSUP RS Haji Adam Malik Medan mengungkapkan bahwa permasalahan spiritual yang dialami oleh ODHA adalah menyalahkan Tuhan, menolak beribadah, beribadah tidak sesuai dengan ketentuan, gangguan dalam beribadah maupun distress spiritual (Tanjung, 2016). Pengalaman suatu penyakit akan menuntut penderitanya untuk mampu menghadapi berbagai macam tekanan sehingga mekanisme koping sangat berpengaruh untuk menentukan keberhasilan individu menghadapi tekanan tersebut. Penderita HIV/AIDS memiliki masalah terkait dengan mekanisme koping. Hal ini ditunjukkan dengan banyaknya penderita HIV/AIDS yang mengisolasi diri dari lingkungannya dan menganggap dirinya tidak berguna lagi sehingga kondisi kejiwaan ODHA akan semakin buruk apabila penderita memiliki masalah dalam mekanisme koping (Siyoto et al., 2016). Apabila ODHA mengalami tekanan mental yang tinggi maka akan berisiko terhadap masalah fisik, psikis, sosial, dan spritual yang dapat mengakibatkan ketidakmampuan memanfaatkan fasilitas kesehatan serta dukungan sosial yang tersedia. Ketidakmampuan individu dalam menangani dan mengendalikan tekanan merupakan penyebab utama yang dapat menurunkan kualitas hidup seseorang (Munongo, 2012)

Strategi koping yang digunakan ODHA pada umumnya berbeda beda. Hal ini salah satunya adalah di tentukan juga oleh factor gender. Perempuan lebih banyak menggunakan strategi koping emotional focused coping karena kecenderungan perempuan yang lebih menggunakan emosi daripada logika (Hidayanti, 
2013). Penelitian lainnya melaporkan tentang penggunaan strategi coping planful problem solving oleh ODHA yaitu suatu strategi penyelesaian masalah yang berfokus pada tindakan yang terencana dan mampu memberikan dampak positif terhadap keberlangsungan hidupnya sebagai ODHA. (Priharwanti \& Raharjo, 2018)

Strategi koping adaptive sangat diperlukan oleh ODHA agar dapat memiliki kemampuan dalam mengurangi berbagai dampak penyakit dan mengatasi tekanan dan tuntutan yang timbul yang pada akhirnya dapat memengaruhi kualitas hidupnya. Setiap individu memiliki mekanisme koping yang berbeda. Koping yang dimunculkan tergantung bagaimana sikap individu dalam menghadapi suatu masalah atau beban yang dihadapi. Fenomena di atas menjadi menarik untuk diteliti secara mendalam karena strategi koping pada ODHA merupakan sesuatu yang unik.

Untuk mencapai tujuan penelitian maka setting penelitian ini dilakukan pada komunitas HIV AIDS di Rumah Cemara Kota Bandung yang merupakan sebuah organisasi berbasis komunitas yang didirikan pada tahun 2003 dengan tujuan memberikan lingkungan yang aman dan positif bagi ODHA dan juga pengguna narkoba.

\section{Metode Penelitian}

Penelitian ini merupakan penelitian deskriptif kualitatif yang dilakukan pada tanggal 14 Maret sampai dengan 1 Agustus 2018. Teknik pengumpulan data dengan wawancara mendalam (indepth interview) terhadap enam partisipan ODHA. Penentuan subjek menggunakan metode purposive sampling dengan kriteria inklusi partisipan ODHA yang tergabung dalam komunitas Rumah Cemara, bersedia menjadi partisipan, dan mampu menjalin komunikasi dengan baik dengan peneliti dan bias membaca serta menulis. Sebelum melakukan wawancara dilakukan inform consent kepada partisipan. Pemilihan partisipan dibantu oleh konselor pendamping yang disesuaikan dengan kriteria inklusi penelitian ini. Peneliti tetap memperhatikan aspek kerahasiaan partisipan.

Peneliti menyiapkan pedoman naskah wawancara, mengatur waktu wawancara, dan mengatur tempat wawancara. Pedoman wawancara dalam penelitian ini disusun berdasarkan masalah keperawatan pasien HIV/AIDS dengan teori adaptasi Roy yang berisikan aspek-aspek dengan masalah fisik, masalah psikis, masalah sosial, masalah spiritual.Wawancara dilakukan $2-3$ kali pada setiap partisipan dengan durasi waktu antara 40 sampai 60 menit sampai tercapai saturasi data. Semua hasil wawancara di rekam dengan hand phone dan dibuat verbatim. Peneliti meyiapkan catatan tertulis untuk mencatat respon verbal maupun non verbal dari partisipan. Jarak wawancara antara peneliti dan partisipan yaitu kurang lebih $50 \mathrm{~cm}$ sampai $90 \mathrm{~cm}$. Wawancara dilakukan di ruangan yang tertutup sesuai dengan kesepakatan dengan partisipan.

Data dianalisis dengan menggunakan analysis interactive model Miles dan Huberman. Peneliti membaca berulang ulang hasil transkripsi. Untuk menganalisis data peneliti melakukan tiga langkah penting yaitu mengkondensasi data dengan cara menyeleksi, memfokuskan data supaya bermakna sesuai dengan tujuan penelitian. Langkah kedua adalah mendisplai data dengan cara menyusun data tersebut menjadi sebuah pola yang memiliki hubungan sehingga mudah dipahami dan selanjutnya adalah menarik kesimpulan untukdimasukan ke dalam tema-tema.

Untuk menjaga keabsahan data dalam penelitian ini maka peneliti melakukan validasi ulang kepada partisipan terkait tema yang muncul apakah sudah sesuai dan juga memperhatikan serta mengecek temuan dengan sumber eksternal yaitu dosen riset keperawatan yang bukan tim peneliti.

\section{Hasil dan Pembahasan}

Penelitian ini melibatkan 6 partisipan dengan karakteristik sebagai berikut:

Table 1. Karakteristik Partisipan

\begin{tabular}{cccc}
\hline $\begin{array}{c}\text { No } \\
\text { partisipan }\end{array}$ & $\begin{array}{c}\text { Jenis } \\
\text { kelamin }\end{array}$ & $\begin{array}{c}\text { Umur } \\
\text { (tahun) }\end{array}$ & Pekerjaan \\
\hline P1 & P & 30 & IRT \\
P2 & P & 28 & IRT \\
P3 & P & 27 & IRT \\
P4 & P & 30 & Tidak bekerja \\
P5 & L & 25 & Pegawai swasta \\
P6 & L & 25 & Pegawai swasta \\
\hline
\end{tabular}

Partisipan dalam penelitian ini terdiri dari enam orang, empat perempuan dan dua laki laki dengan umur berkisar antara 25 tahun sampai 30 tahun. Durasi partisipan terdiagnosis penyakit antara satu sampai empat tahun. Berdasarkan pekerjaan tiga partisipan merupakan ibu rumah tangga, satu orang tidak bekerja dan dua orang pegawai swasta. 
Faletehan Health Journal, 8 (1) (2021) 22-30

Table 2. Analisis Tematik

\begin{tabular}{|c|c|c|}
\hline Tema & Subtema & Kategori \\
\hline \multirow[b]{2}{*}{ Pasrah pada Tuhan } & $\begin{array}{l}\text { Pasrah terhadap yang sudah } \\
\text { terjadi }\end{array}$ & $\begin{array}{l}\text { Nyerahin sama yang diatas, } \\
\text { Sudah pasrah. }\end{array}$ \\
\hline & $\begin{array}{l}\text { Mencoba Ikhlas, Harus } \\
\text { tawakal }\end{array}$ & $\begin{array}{l}\text { Mau gimana lagi, } \\
\text { Nerima saja, } \\
\text { Mungkin sudah takdir, } \\
\text { Jalani saja, }\end{array}$ \\
\hline \multirow{2}{*}{$\begin{array}{l}\text { Tidak ingin } \\
\text { memikirkan penyakit }\end{array}$} & $\begin{array}{l}\text { Tidak Ingin memikirkan } \\
\text { penyakit }\end{array}$ & $\begin{array}{l}\text { tidak ingin memikirkan penyakit, } \\
\text { tidak peduli, } \\
\text { cukup tahu. }\end{array}$ \\
\hline & $\begin{array}{c}\text { Diam seolah Tidak Terjadi } \\
\text { Apa-Apa } \\
\end{array}$ & $\begin{array}{l}\text { Diam tidakmenceritakan pada siapa siapa } \\
\text { Diam seolah tidak terjadi apa apa apa }\end{array}$ \\
\hline Pengalihan Masalah & $\begin{array}{c}\text { Mencari Kegiatan atau } \\
\text { Aktivitas }\end{array}$ & $\begin{array}{l}\text { Kumpul dengan komunitas } \\
\text { Bermain } \\
\text { ke pengajian } \\
\text { berlibur }\end{array}$ \\
\hline $\begin{array}{l}\text { Berupaya untuk } \\
\text { bangkit }\end{array}$ & $\begin{array}{l}\text { Bangkit untuk pemenuhan } \\
\text { tanggung jawab }\end{array}$ & $\begin{array}{l}\text { Fokus merawat suami } \\
\text { bangkit karena anak } \\
\text { semangat karena orang tua }\end{array}$ \\
\hline \multirow[b]{2}{*}{$\begin{array}{l}\text { Upaya mengtasi } \\
\text { Masalah }\end{array}$} & $\begin{array}{l}\text { Merencanakan Pemecahan } \\
\text { Masalah }\end{array}$ & $\begin{array}{l}\text { Mencari Informasi tentang Penyakit dan } \\
\text { Pengobatan, } \\
\text { Konsultasi dengan Tenaga Medis }\end{array}$ \\
\hline & $\begin{array}{c}\text { Melakukan pemecahan } \\
\text { masalah sehubungan dengan } \\
\text { terapi }\end{array}$ & $\begin{array}{l}\text { Mencari obat pendukung, } \\
\text { mengkonsumi makanan atau minuman } \\
\text { manis, } \\
\text { mengatur makanan dan memperbanyak } \\
\text { makan }\end{array}$ \\
\hline $\begin{array}{l}\text { Menyembunyikan } \\
\text { Status }\end{array}$ & $\begin{array}{l}\text { Menutup Status sebagai } \\
\text { ODHA }\end{array}$ & $\begin{array}{l}\text { Belum siap takut stigma } \\
\text { Lebih baik tertutup, } \\
\text { Lingkungan belum ngerti, } \\
\text { ngasih tau ke sesama penyanyang saja, } \\
\text { Takut pada ngejauh }\end{array}$ \\
\hline
\end{tabular}

Berdasarkan hasil analisis data dari keenam partisipan didapatkan enam tema yaitu: Pasrah pada Tuhan, Tidak ingin memikirkan penyakit, Pengalihan Masalah, Berupaya untuk Bangkit, Upaya mengatasi Masalah dan Menyembunyikan Status. Keenam tema disajikan dalam tabel berikut:

Dibawah ini dijelaskan lebih lanjut tentang tema yang ditemukan dan pembahasannya

\section{Pasrah pada Tuhan}

Pada penelitian ini ditemukan bahwa seluruh partisipan melakukan strategi koping pasrah pada Tuhan. Pernyataan seluruh partisipan yang mendukung tema ini dapat dilihat dari kalimat-kalimat hasil wawancara sebagai berikut:
"Waktu itu saya bener-bener nyerahin semuanya ke yang di atas" (P1)

"Mungkin ini udah resikonya mungkin nasibnya kaya gini ya udah gimana lagi.. pasrah aja" (P2)

"Sedih ga percaya tapi ya udah terimain aja" (P3)

"Mau gimana lagi da kehendak Allah ya udah nerima aja dengan apa adanya" (P4) "Saya mah udah pasrah kalo buat diri saya sendiri. Allah ngasihnya seperti ini jadi ya sekarang saya mah jalani aja" (P5) "saya sempet pasrah gitu" (P6)

Kepasrahan pada Tuhan merupakan tema pertama yang ditemukan pada penelitian ini. Berdasarkan wawancara dengan partisipan, 
tema ini muncul saat partisipan mengetahui bahwa mereka terdiagnosis penyakit ini dan dinyatakan sebagai ODHA. Strategi koping ini adalah bentuk pertahanan diri dalam menghadapi masalah merupakan bentuk stategi koping yang fokus terhadap nilai-nilai keagamaan. Bentuk strategi koping ini termasuk kedalam emotional focused coping. Hasil pernyataan keenam partisipan tersebut sesuai dengan teori Lazarus dan Folkman (1984) dalam (Miranda, 2013) yang menjelaskan bahwa emotional focused coping dapat dilakukan melalui positif reappraisal yaitu usaha individu mengatur emosinya dalam rangka menyesuaikan diri terhadap situasi penuh tekanan dengan mencari makna positif, mencari arti atau keuntungan dari permasalahan tersebut, serta terfokus pada pengembangan diri termasuk melibatkan halhal yang bersifat religious

\section{Tidak mau memikirkan penyakit}

Tema kedua dari penelitian ini adalah Tidak mau memikirkan penyakit. Subtema yang mendukung tema kedua ini ada dua yaitu pertama tidak memikirkan masalah dengan serius dilakukan oleh dua partisipan yaitu P1 dan P2 dengan kategori tidak ingin memikirkan penyakit, tidak peduli, dan cukup tahu. Subtema kedua diam seolah tidak terjadi apa-apa dilakukan oleh empat partisipan yaitu P3, P4, P5, dan P6 dengan kategori diam. Dibawah ini beberapa petikan hasil wawancara mendalam yang diperoleh yang mendukung tema ini

\footnotetext{
"Saya ga mau dari awal mikirin kalo ada penyakit di dalam tubuh saya gitu, toh saya juga sehat" (P1)

"Sekarang mah udah cuek aja kalau minum obat itung-itung vitamin weh itung-itung temen nasi buat kebutuhan hidup" (P2)

"Ya pas sedih diem pertama sih diem em.. ga pernah cerita apa-apa" (P3)

"Lebih banyak diem" (P4, P5, P6)
}

Tema ini sesuai dengan penelitian tentang penerimaan diri perempuan pengidap HIV AIDS di Bali (Putri \& Tobing, 2016) yang melaporkan bahwa ODHA hanya fokus menjalani kehidupannya serta tidak memikirkan apa yang orang lain katakan. Tidak ingin memikirkan penyakit merupakan suatu bentuk koping penghindaran dari masalah yang menghambat fungsi integrasi. Apabila koping ini dilakukan maka penyelesaian masalah tidak akan terjadi karena akan menghambat ODHA dalam melakukan penyelesaikan masalah sehingga diperlukan perhatian yang lebih terhadap ODHA khususnya dalam peningkatan strategi koping

\section{Pengalihan Masalah}

Seluruh partisipan melakukan strategi koping pengalihan masalah dengan subtema mencari kegiatan atau aktivitas. Kategori pertama yang mendukung subtema ini adalah kumpul dengan komunitas. P1 dan P2 melakukan pengalihan masalah dengan kumpul bersama komunitas sesama ODHA. Kategori kedua yang mendukung subtema ini adalah bermain. P3 dan P5 melakukan pengalihan masalah dengan bermain saat merasa down dan tertekan. Kategori ketiga yang mendukung subtema ini adalah ke pengajian. P4 melakukan pengalihan masalah dengan mengikuti kegiatan pengajian. Kategori keempat yang mendukung subtema ini adalah berlibur. P6 juga melakukan pengalihan masalah dengan berlibur. Berikut ini cuplikan hasil wawancara yang mendukung tema pengalihan masalah

"Lebih sering keluar buat main sama komunitas kumpul-kumpul cari cari kegiatan lain" (P1)

"Jadi lebih keluar sering keluar rumah (Kumpul dengan komunitas)" (P2)

"Paling main ke luar jadi kalo ngerasa down cari aktivitas lain" (P3, P5)

"Lebih sering ke pengajian ngehibur diri yah" (P4)

"Pergi kemana gitu kaya ke tamantaman daerah yang sejuk” (P6)

Strategi koping ini termasuk kedalam emotional focused problem yaitu berfokus pada emosi. Merujuk pada karakteristik gender partisipan pada penelitian ini yang lebih banyak perempuan sehingga lebih cenderung menggunakan emosi dalam menangani masalah yang dihadapi. Strategi 
Faletehan Health Journal, 8 (1) (2021) 22-30

ini umum dilakukan oleh orang orang yang mengalami stress dan tidak selalu efektif untuk penanganan jangka panjang terutama untuk stress yang harus ditangani segera. Hasil penelitian ini sejalan dengan penelitian yang melaporkan bahwa ODHA mencoba menghindari stress dengan terlibat dalam aktivitas kelompok.(Nugrahati Carsita et al., 2016). Tetapi apabila mencermati hasil tema pengalihan masalah yang dilakukan oleh partisipan kegiatan yang dilakukan cenderung masih postif yaitu pergi ke pengajian atau ke taman

\section{Berusaha untuk Bangkit}

Seluruh partisipan melakukan strategi koping berusaha untuk bangkit dengan diperkuat oleh subtema bangkit untuk pemenuhan tanggung jawab. P1 bangkit dari kesedihan dan melakukan tanggung jawab dengan terfokus merawat suami. Kategori kedua yang mendukung subtema ini adalah berusaha bangkit untuk anak. P2 dan P4 berusaha bangkit dari penyakitnya karena tanggung jawab yang harus dipenuhi terhadap anak. Kategori ketiga yang mendukung subtema ini adalah P3, P5, dan P6 yang bangkit dari penyakitnya dengan mengingat dan memenuhi tanggung jawab terhadap orang tua. Berikut beberapa pernyataan partisipan yang mendukung tema berusaha untuk bangkit

"Saya langsung terfokus ke suami yang perlu perawatan saya" (PI)

"Saya teh kasian anak gitu, anak dicuekin saya tidur terus jadi saya teh berusaha buat bangkit lagi gitu" (P2)

"Saya punya anak yang perjalanannya masih panjang penyemangat saya mah anak sama keluarga $(P 4)$

"Orang tua saya jauh, masa gini terus, mulai semangat lah dari situ inget sama mamah papah di sana" (P3)

"Saya kan anak pertama terus orang tua udah tua jadi kasian gitu, ya dari situ lah ada semangat lagi buat diri saya" (P5)

"Mamah yang selalu semangatin kalo saya down saya lebih inget ke mamah aja yang buat saya semangat perjuangan mamah" (P6)
Ungkapan partisipan tersebut merupakan ungkapan pendukung terhadap tema berusaha untuk bangkit. Dalam penelitian ini diketahui seluruh partisipan memiliki rasa tanggung jawab yang besar terhadap keluarganya. Persepsi yang positif ini sangat berguna dalam meningkatkan motivasi hidup penderita. ODHA yang mendapat dukungan sosial dari orang orang yang berarti dan juga petugas kesehatan akan merasa dihargai dan dicintai hal ini dapat menyebabkan semangat hidup yang lebih lama. Penelitian tentang penerimaan dukungan sosial melaporkan bahwa ada hubungan signifikan antara dukungan sosial dengan kebermaknaan hidup bagi penderita HIV AIDS.(Astuti \& Budiyani, 2013). Penelitian lain yang selaras adalah bahwa dukungan sosial yang paling penting pada ODHA yang sedang mendapat ARV juga didapatkan dari teman sebaya sesama ODHA karena sesama ODHA seperti keluarga baru yang bersama sama menjalani kehidupan dengan penuh suka duka (Ariatama et al., 2020)

\section{Upaya Mengatasi Masalah}

Tema kelima dalam penelitiian ini yaitu upaya mengatasi masalah. Seluruh partisipan mengatasi masalah dengan cara berbeda. Berdasarkan hasil wawancara mendalam pada partisipan ditemukan tema strategi koping yang berfokus pada masalah yaitu upaya mengatasi masalah. Tema ini didukung oleh dua subtema yaitu merencanakan pemecahan masalah dan melakukan pemecahan masalah sehubungan dengan terapi. Sub tema merencanakan pemecahan masalah ini diperkuat oleh beberapa kategori yaitu mencari informasi tentang penyakit dan pengobatan, konsultasi dengan tenaga medis, mencari obat pendukung, mengkonsumi makanan atau minuman manis,mengatur makanan dan memperbanyak makan sedangkan sub tema melakukan pemecahan masalah sehubungan dengan terapi dilakukan dengan cara berbeda beda, P1 berkonsultasi dengan konselor, orangtuanya dan dokter. P2 mengikui program di klinik dan mengikuti pelatihan. Berikut petikan hasil wawancara yang menguatkan tema ini 
Faletehan Health Journal, 8 (1) (2021) 22-30

www. journal.Ippm-stikesfa.ac.id/ojs/index.php/FHJ

ISSN 2088-673X | 2597-8667

"Saya tanya ke konselornya "teh, saya harus gimana?" (P1)

"Saya cerita sama mama em.. sama ibu sama bapak untuk kedepannya bagaimana?" (P1)

"Sempet nanya ke psikiater dari situ mulai membuka diri" (P4)

"Kata petugas ikutan program aja ke klinik T dianter sama Ny. E dan dikasih obat ARV" (P2)

"Suka ikutan pelatihan ingin tahu gitu (tentang HIV/AIDS)" (P2)

"Konsultasi terus ke dokter sebulan dua kali lah" (Pl)

"Gatau yah saya bisa menularkan lewat apa saya sharing ke dokter ternyata dari batuk itu engga sampai menularkan" (P5)

"Saya konsultasi ke dokter" (P6)

Upaya mengatasi masalah merupakan bentuk strategi koping yang menentukan keberhasilan individu dalam menghentikan suatu masalah. Bentuk koping ini termasuk bentuk koping positif karena merujuk pada pemecahan masalah. Temuan dalam penelitian ini menunjukan upaya ODHA dalam melakukan usaha untuk mengubah situasi tekanan dengan berusaha untuk memikirkan dan mempertimbangkan penyelesaian dan berusaha melakukan pemecahan masalah (Planfull Problem Solving) dengan meminta pendapat dan pandangan dari orang lain tentang masalah yang dihadapi. (Priharwanti \& Raharjo, 2018). Tema ini juga diperkuat oleh penelitian yang dilakukan oleh (Burhan et al., 2014) tentang gambaran kebermaknaan hidup ODHA serta tinjauannya menurut Islam yang menyatakan bahwa salah satu upaya mengatasi masalah adalah dengan menceritakan masalah dan meminta dukungan secara langsung pada keluarga sehingga menjadi lebih bahagia dan bersemangat dalam menjalani kehidupan. Disamping itu pemecahan masalah dengan mencari informasi mengenai penyakit yang diderita sehingga ODHA akan membuat penderita lebih mudah menyesuaikan diri serta dapat menerima penyakitnya dengan lebih cepat.

\section{Menyembunyikan status kesehatan}

Seluruh partisipan melakukan koping penyembunyian status kesehatan dengan subtema menutup status sebagai ODHA. Kategori yang mendukung subtema ini adalah ketidaksiapan membuka status. P3 dan P5 menyembunyikan status sebagai ODHA terhadap seluruh keluarga. P6 hanya membuka status terhadap ibunya sehingga keluarga seperti ayah dan saudara kandung tidak mengetahui statusnya sebagai ODHA. $\mathrm{P} 1$, P2, dan $\mathrm{P} 4$ menyembunyikan status sebagai ODHA terhadap lingkungan, khususnya di lingkungan rumah. Seluruh partisipan hanya membuka status terhadap tenaga kesehatan, sesama ODHA, dan orang yang dapat dipercaya. Berikut cuplikan hasil wawancara yang berkaitan dengan tema ini

"Kalo membuka status orang tua saya juga belum siap kalo ada stigma atau pikiran jelek tentang kita" (P1)

"Ga berani cerita ada juga sih aku ga cerita kan takutnya dia ngejauh gitu" (P2)

"Cerita ke keluarga saat ini mah engga kali yah" (P3)

"Ke orang lain mah tertutup belum open status apalagi daerah saya masih perkampungan masih awam ke masalah seperti itu gitu ada keraguan" (P4)

"Sampe sekarang jujur orang tua gatau em.. ngasih tau paling ke sesama sih ke sesama penyandang kalo ke orang lain ya engga" (P5)

"tertutup sama keluarga di rumah yang tau cuma si mamah aja” (P6

Menyembunyikan status kesehatan muncul akibat kekhawatiran partisipan mengalami penolakan dan stigmatisasi sehingga seluruh partisipan melakukan pertimbangan penuh dan hanya membuka status terhadap orang-orang yang sudah dipercaya. Tema ini tidak sesuai dengan teori koping manapun namun didukung oleh teori adaptasi Roy yaitu ODHA menyembunyikan status kesehatan untuk menghindari stigmatisasi(Nursalam. \& Kurniawati N.D., 2007) serta didukung oleh penelitian tentang strategi komunikasi pada ODHA yang menyatakan bahwa ODHA cenderung menyembunyikan statusnya 
Faletehan Health Journal, 8 (1) (2021) 22-30 www. journal.Ippm-stikesfa.ac.id/ojs/index.php/FHJ ISSN 2088-673X | 2597-8667

bahkan kepada keluarga dekat sekalipun. (Makmur, 2018)

\section{Simpulan}

Berdasarkan hasil penelitian yang dilakukan terhadap enam partisipan ODHA di Komunitas Rumah Cemara Kota Bandung terdapat enam tema strategi koping yaitu: 1) Pasrah pada Tuhan 2) Tidak ingin memikirkan penyakit 3) Pengalihan masalah, 4) Berusaha untuk bangkit 5) Upaya mengatasi masalah 6)Menyembunyikan status Kesehatan. Berdasarkan ke enam tema yang ditemukan, partisipan ODHA cenderung melakukan emotional focused coping. Adapun tema Menyembunyikan status kesehatan yang tidak sesuai dengan teori koping manapun namun didukung oleh teori adaptasi dan penelitian yang menyatakan ODHA menyembunyikan status kesehatan. Sehingga diharapkan perawat dapat menjalankan strategi intervensi dengan memberikan konseling maupun edukasi strategi koping yang adaptif kepada penderita dan keluarganya dengan cara membantu memberikan alternatif penyelesaikan masalah serta melatih ketrampilan ODHA agar memiliki kemampuan dalam menyelesaikan masalah secara konstruktif.

\section{Referensi}

Ariatama, E. M., Respati, T., \& Nurhayati, E. (2020). Kondisi Psikologi, Sosial, dan Spiritual pada Orang dengan HIV/AIDS Selama Pengobatan Antiretroviral di Komisi Penanggulangan AIDS Kota Bogor Tahun 2019. Jurnal Integrasi Kesehatan \& Sains, 2(2), https://doi.org/10.29313/jiks.v2i2.5601

Astuti \& Budiyani. (2013). Hubungan antara dukungan sosial yang diterima dengan kebermaknaan hidup pada ODHA. Jurnal Psikologi Universitas Mercu Buana Yogyakarta. Universitas Mercu Buana Yogyakarta ABSTRAK.

Burhan, R. F., Fourianalistyawati, E., \& Zuhroni. (2014). Jurnal Psikogenesis. Vol. 2, No. 2/ Juni 2014. 2(2).

Dahlui, M., Azahar, N., Bulgiba, A., Zaki, R., Oche, O. M., Adekunjo, F. O., \& Chinna, K. (2015). HIV/AIDS related stigma and discrimination against PLWHA in Nigerian population. PLoS ONE, 10(12), 1-11. https://doi.org/10.1371/journal.pone.0143749

Dinas Kesehatan Provinsi Jawa Barat. (2017).
Profil Kesehatan Dinas Kesehatan Provinsi Jawa Barat 2017. Diskes Jabarprov, 52.

Hidayanti, E. (2013). Strategi Coping Stress Perempuan Dengan Hiv/Aids. Sawwa: Jurnal Studi Gender, 9(1), 89-106.

Kementrian Kesehatan RI. (2018). General situation of HIV/AIDS and HIV test. In Pusat Data dan Informasi Kementrian Kesehatan RI (pp. 1-12).

Makmur, R. (2018). Strategi Komunikasi Orang Dengan Hiv Aids (Odha) Menghadapi Stigma Masyarakat. LUGAS Jurnal Komunikasi, 1(1), 68-83. https://doi.org/10.31334/j1.v1i1.105

Miranda, D. (2013). Srategi Koping dan Kelelahan Emosional pada Ibu yang Memiliki Anak Berkebutuhan Khusus. E-HJournal Psikologi, 1(2), 123-135.

Munongo, E. (2012). Factors that influence parents to disclose or not to disclose HIV status to their children who are living with HIV / AIDS in the greater Harare area in Zimbabwe. March, 41.

Mutumba, M., Baurmeister, J. A., Musiime, V., Byaruhanga, J., Francis, K., Snow, R. C., \& Alexander C. Tsai. (2015). Psychosocial Challenges and Strategies for Coping with HIV Among Adolescents in Uganda: A Qualitative Study. AIDS Patients Care and STDs, Vol.29, No(Behavioral and Psychological Research), 86-94.

Nugrahati Carsita, W., Winarni, I., \& Lestari, R. (2016). Studi Fenomenologi: Orang Dengan Hiv Aids (Odha) Dalam Menjalani SelfDisclosure Di Wilayah Kerja Puskesmas Bongas. Jurnal Ilmu Keperawatan (Journal of Nursing Science), 4(2), 205-224. https://doi.org/10.21776/ub.jik.2016.004.02.9

Nursalam. \& Kurniawati N.D. (2007). Asuhan Keperawatan Pada Pasien Terinfeksi HIV/AIDS. Salemba Medika: (Issue May 2020).

Pardita, D. P. Y., \& Sudibia, I. K. (2016). ANALISIS DAMPAK SOSIAL, EKONOMI, DAN PSIKOLOGIS PENDERITA HIV AIDS DI KOTA DENPASAR. Buletin Studi Ekonomi.

Priharwanti, A., \& Raharjo, B. B. (2018). Problems Focused Coping Penderita HIV Positif. Public Health Perspective Journal, 2(2), 131-139.

Putri, I. A. K., \& Tobing, D. H. (2016). Gambaran Penerimaan Diri Pada Perempuan Bali Pengidap HIV-AIDS. Jurnal Psikologi 
Udayana, 3(9), 395-406.

Silva, R. T. S., da Silva, R. A. R., Rodrigues, I. D. C. V., de Souza Neto, V. L., da Silva, B. C. O., \& Souza, F. M. de L. C. (2018). Estratégias de enfrentamento utilizadas por pessoas vivendo com aids frente à situação da doença. Revista Latino-Americana de Enfermagem, 26. https://doi.org/10.1590/1518-8345.2284.2985

Siyoto, S.-, Peristiowati, Y.-, \& Agustin, E.-. (2016). Analisis Faktor Yang Berhubungan Dengan Mekanisme Koping Pada Odha Dengan Pendekatan Teori Adaptasi Callista
Roy. Jurnal NERS, 11(2), 256. https://doi.org/10.20473/jn.v11i22016.256260

Tanjung, D. M. (2016). Karakteristik Distress Spiritual pada Orang Dengan HIV/AIDS (ODHA) di RSUP Haji Adam Malik Medan. $1-60$.

http://repository.usu.ac.id/handle/123456789/ 63305

dan http://repository.usu.ac.id/bitstream/handle/1 23456789/63305/Chapter II.pdf?sequence $=4 \&$ isAllowed $=\mathrm{y}$ 